JURNAL EINSTEIN
Jurnal Hasil Penelitian Bindang Fisika
$\begin{gathered}\text { Available online http://jurnal.unimed.ac.id/2012/index.php/inpafi } \\ \text { e-issn: } 2407-747 x, p-i s s n \text { 2338-1981 }\end{gathered}$

\title{
PENGOLAHAN TEMPURUNG KEMIRI SEBAGAI KARBON AKTIF DENGAN VARIASI AKTIVATOR ASAM FOSFAT
}

\author{
Nurul Huda Sulaiman, Lastri Aryani Malau, Fadhillah Husna Lubis, Nurhailani Br \\ Harahap, Fadly Rikki Manalu, Agus Kembaren2)
}

\author{
Jurusan Kimia, Fakultas Matematika dan Ilmu Pengetahuan Alam, Universitas Negeri Medan, \\ Indonesia \\ nurulhuda8892@gmail.com
}

Diterima April 2017; Disetujui Mei 2017; Dipublikasikan Juni 2017

\begin{abstract}
ABSTRAK
Tempurung kemiri merupakan limbah organik yang dapat diuraikan namun dengan teksturnya yang cukup keras sehingga membutuhkan waktu untuk menguraikannya secara alamiah, sehingga kulit kemiri menjadi limbah yang sangat meresahkan masyarakat sehingga dilakukan berbagai upaya untuk memanfaatkan limbah kulit kemiri.Proses pembuatan karbon aktif melalui tiga tahapan yaitu proses pengarangan atau kabonisasi, proses aktivasi dan proses dehidrasi. Untuk menjadi arang, tempurung kemiri awalnya dikeringkan diterik matahari dan dioven pada suhu $110^{\circ} \mathrm{C}$ selama $1 \mathrm{jam}$. Kemudian tempurung kemiri di furnace pada suhu $700^{\circ} \mathrm{C}$ selama 2 jam agar menjadi arang. Arang yang dihasilkan direndam dalam larutan H3PO4 pada konsentrasi 2,5\%, 5,0\% dan 7,5\% selama 24 jam. Selanjutnya dioven untuk menghilangkan kadar air pada arang. Arang yang sudah dioven diaktivasi termal dalam furnace pada suhu $700^{\circ} \mathrm{C}$ selama 2 jam. Yang dianalisa dalam penelitian ini adalah kadar air, kadar abu, daya serap terhadap iodium, dan kristalinitas. Dari uji kualitas karbon aktif yang dilakukan, kualitas karbon aktif yang terbaik diperoleh pada konsentrasi asam posfat 7,5\% dengan kadar air 6,95 $\%$, kadar abu 2,38\%, daya serap terhadap kadar iod sebesar 602,91 mg/g yang memenuhi standar SNI 06-3703-1995. Hasil yang di dapat dari penelitian ini yaitu semakin tinggi konsentrasi zat aktivator, dan waktu aktivasi maka semakin tinggi daya serap karbon aktif.
\end{abstract}

Kata Kunci: Karbon aktif, Tempurung Kemiri, Asam Fosfat

\section{PENDAHULUAN}

Kulit kemiri merupakan limbah organik yang dapat diuraikan namun dengan teksturnya yang cukup keras sehingga membutuhkan waktu untuk menguraikannya secara alamiah, sehingga kulit kemiri menjadi limbah yang sangat meresahkan masyarakat sehingga dilakukan berbagai upaya untuk memanfaatkan limbah kulit kemiri. Jumlah produksi buah kemiri di
Indonesia pada tahun 2002 menurut Biro Pusat Statistik adalah sebesar 1.703.362 Kg (BPS). Pemanfaatan limbah kulit kemiri ini dimaksudkan selain untuk menanggulangi penumpukkan limbah kulit kemiri juga diharapkan dapat menghasilkan produk yang aman dan ramah lingkungan. Dengan memperhatikan faktor lingkungan tersebut, maka kulit kemiri dapat dimanfaatkan sebagai 
bahan baku pembuatan karbon aktif. (Meilita dan Tuti, 2003).

Industri pembuatan karbon aktif di Indonesia telah mengalami kemajuan yang cukup pesat. Hal ini disebabkan oleh semakin meningkatnya permintaan pasar, baik di dalam negeri maupun untuk diekspor ke luar negeri. Peningkatan kebutuhan akan karbon aktif ini diakibatkan oleh semakin banyaknya aplikasi karbon aktif untuk industri dan berbagai peralatan bantu manusia. Karbon aktif dapat dipergunakan untuk berbagai industri, antara lain yaitu industri obat-obatan, makanan, minuman, pengolahan air (penjernihan air) dan lain-lain. Hampir 70\% produk karbon aktif digunakan untuk pemurnian dalam sektor minyak kelapa, farmasi dan kimia. (Pari dan Sailah, 2001).

Karbon aktif dapat dibuat melalui dua tahap, yaitu tahap karbonisasi dan aktivasi. Karbonisasi merupakan proses pengarangan dalam ruangan tanpa adanya oksigen dan bahan kimia lainnya, sedangkan aktivasi diperlukan untuk mengubah hasil karbonisasi menjadi adsorben yang memiliki luas permukaan yang besar. Aktivasi adalah perlakuan terhadap arang yang bertujuan untuk memperbesar pori yaitu dengan cara memecahkan ikatan hidrokarbon atau mengoksidasi molekul permukaan sehingga arang mengalami perubahan sifat, baik fisika atau kimia, yaitu luas permukaannya bertambah besar dan berpengaruh terhadap daya adsorpsi. (Wulandari,dkk, 2012).

Berdasarkan SNI 06-3730-1995 tentang arang aktif teknis, arang aktif berbentuk serbuk yang berkualitas baik memiliki kadar air maksimal sebesar 15\%, kadar zat mudah menguap maksimal 25\%, kadar abu maksimal 10\% dan kadar karbon minimal 65\%. Untuk daya serapnya, arang aktif yang baik memiliki daya serap terhadap I2 minimal sebesar $750 \mathrm{mg} / \mathrm{g}$ dan daya serap terhadap metilen biru minimal sebesar 120 $\mathrm{mg} / \mathrm{g}$ (Sudrajat dan Pari, 2011).

Tujuan dari penelitian ini adalah mengolah tempurung kemiri untuk dijadikan karbon aktif menggunakan aktivator asam fosfat dengan konsentrasi yang bervariasi.

\section{Alat dan bahan}

\section{METODE PENELITIAN}

Alat yang digunakan dalam penelitian ini adalah furnace, oven listrik, neraca analitis, cawan porselen, lumpang dan alu, gelas kimia, erlenmeyer, desikator, ayakan 150 mesh dan alat titrasi.

Bahan utama yang digunakan untuk membuat karbon aktif yaitu tempurung kemiri yang diambil dari kota Tiga Binanga, Lau Baleng, kecamatan Mardinding, kabupaten Karo, provinsi Sumatera Utara, $\mathrm{H}_{3} \mathrm{PO}_{4}$, kertas saring, aquades, indicator universal, amilum dan iodium.

\section{Prosedur Kerja}

Pembuatan karbon aktif dari tempurung kemiri ini dilakukan melalui tiga tahap yang meliputi, pengarangan, pengaktifan dan pengujian karbon aktif.

Pengarangan tempurung kemiri dilakukan didalam furnace pada suhu $700^{\circ} \mathrm{C}$ yang sebelumnya tempurun kemiri sudah mengalami pengeringan baik di bawah sinar matahari maupun di dalam oven dengan tujuan mengurangi kadar air pada tempurung kemiri. Setelah pengarangan selesai, arang yang dihasilkan tersebut digiling di lumpang dan alu. Lalu diayak dengan ukuran $150 \mu \mathrm{m}$.

Pengaktifan arang dilakukan dengan merendam arang di dalam larutan activator $\left(\mathrm{H}_{3} \mathrm{PO}_{4}\right)$ dengan konsentrasi 2,5\%, 5,0\%, dan 7,5\% selama 24 jam. Kemudian arang disaring dengan menggunakan kertas saring. Setelah itu arang aktif dicuci dengan aquadest hingga $\mathrm{pH} 7$, lalu disaring lagi dengan menggunakan kertas saring. Dari langkah ini akan didapat sampel pasta arang. Sampel yang telah didapat dikeringkan di dalam oven pada suhu $200^{\circ} \mathrm{C}$ selama 1 jam.

Pengujian arang yang sudah aktif dapat dilakukan dengan beberapa cara, yaitu :

1. Uji Kadar Air

Kadar air ditentukan dengan cara pengeringan di dalam oven. Sebanyak 5 gram contoh ditimbang dengan teliti dan ditempatkan di dalam cawan porselen yang telah diketahui bobotnya, kemudian dikeringkan dalam oven pada suhu $105^{\circ} \mathrm{C}$ selama 1 jam. Kemudian didinginkan di dalam desikator dan ditimbang. Kadar air dapat dihitung dengan persamaan berikut: 


$$
\text { Kadar air } \%=\frac{a-b}{a} \times 100 \%
$$

Dimana : $\mathrm{a}=$ massa awal karbon aktif $(\mathrm{g})$

\section{Uji Kadar Abu}

$$
\mathrm{b}=\text { massa akhir karbon aktif (g) }
$$

Sebanyak 5 gram arang aktif dimasukkan dalam cawan poselen, kemudian di furnace pada suhu $700^{\circ} \mathrm{C}$, kemudian didinginkan dalam deksikator hingga suhu konstan lalu ditimbang. Kadar abu karbon dapat dihitung dengan menggunakan rumus sebagai berikut :

$$
\text { Kadar } a b u \%=\frac{a-b}{a} \times 100 \%
$$

Dimana $: \mathrm{a}=$ massa awal karbon aktif $(\mathrm{g})$

$$
\mathrm{b}=\text { massa akhir karbon aktif }(\mathrm{g})
$$

3. Uji daya serap terhadap iodium

Pengujian terhadap daya serap iodium dilakukan dengan menimbang karbon aktif 5 gram dan campurkan dengan $10 \mathrm{ml}$ larutan Iodium $0,1 \mathrm{~N}$. Kocok dengan alat pengocok selama 15 menit. Setelah itu pindahkan ke dalam tabung sentrifugal sampai karbon aktif turun, kemudian mengambil $10 \mathrm{ml}$ cairan itu dan titrasi dengan larutan natrium tiosulfat $0,1 \mathrm{~N}$. Jika warna kuning pada larutan mulai samar, tambahakna larutan amilum $1 \%$ sebagai indikator. Titrasi kembali warna biru tua hingga menjadi warna bening. Rumus perhitungan daya serap Iodium yaitu sebagai berikut:

Daya serap iod $=\frac{A-\frac{B \times N(\mathrm{Na} 2 \mathrm{~S} 2 \mathrm{O} 3)}{N(\text { iodin })} 126,93 \mathrm{fp}}{\propto}$

Dimana :

$\mathrm{A}=$ Volume larutan iodin $(\mathrm{mL})$

$\mathrm{B}=$ Volume Na2S2O3 yang terpakai $(\mathrm{mL})$

$\mathrm{fp}=$ faktor pengenceran

$\alpha=$ bobot karbon aktif (g)

$\mathrm{N}\left(\mathrm{Na}_{2} \mathrm{~S}_{2} \mathrm{O}_{3}\right)=$ kosentrasi $\mathrm{Na}_{2} \mathrm{~S}_{2} \mathrm{O}_{3}(\mathrm{~N})$

$\mathrm{N}($ iodin $)=$ kosentrasi iodin $(\mathrm{N})$

126,93 = jumlah iodin sesuai $1 \mathrm{~mL}$ larutan $\mathrm{Na}_{2} \mathrm{~S}_{2} \mathrm{O}_{3}$

\section{HASIL DAN PEMBAHASAN}

Dari penelitian yang telah dilakukan diperoleh hasil sebagai berikut:

\section{a. Arang Aktif}

Dari serangkaian prosedur yang telah dilakukan, bahan baku tempurung kemiri dikeringkan secara alami dibawah sinar matahari sampai kering udara, kemudian dilakukan pengovenan dengan suhu $110^{\circ} \mathrm{C}$ dengan penyusutan massa mencapai $10-20 \%$ dengan tujuan mengurangi kadar air sehingga memudahkan pada proses pembakaran/pengarangan pada tempurung kemiri.

Pada proses pembakaran tempurung kemiri menggunakan furnace dengan suhu $700^{\circ} \mathrm{C}$ selama 2 jam. Setelah itu arang di tumbuk dengan lumpang hingga halus dan diayak dengan ukuran $150 \mu \mathrm{m}$.Setelah proses ini selesai selanjutnya arang aktif tersebut di aktivasi secara kimia menggunakan $\mathrm{H}_{3} \mathrm{PO}_{4}$ dengan konsentrasi $2,5 \%, 5 \%$ dan $7,5 \%$.

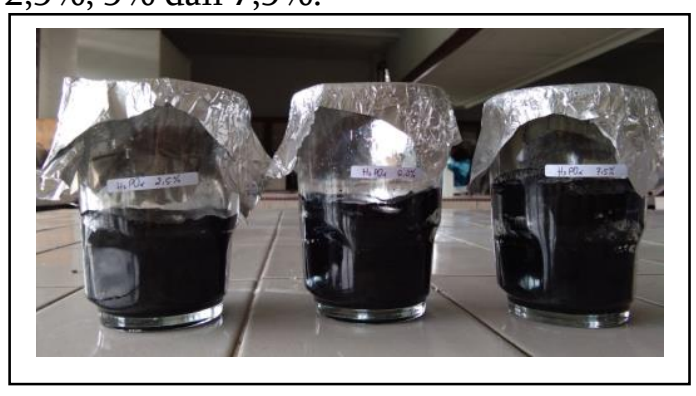

Gambar 1. Arang direndam dengan asam posfat pada konsentrasi 2,5\%, 5\% dan 7,5\%.

b. Uji Kadar Air

Penurunan kadar air sangat erat hubungannya dengan temperatur. Semakin tinggi temperature pengeringan maka semakin sedikit kadar air yang terkandung dalam arang aktif sehingga dapat menghasilkan pori yang semakin besar. Semakin besar pori-pori maka luas permukaan karbon aktif semakin bertambah, sehingga mengakibatkan meningkatnya kemampuan adsorpsi dari karbon aktif. Dengan meningkatnya kemampuan adsorbsi dari karbon aktif maka semakin baik kualitas dari karbon aktif tersebut.

Tabel 1. Hubungan antara konsentrasi aktivator dengan kadar air.

\begin{tabular}{ccc}
\hline No. & $\begin{array}{c}\text { Konsentrasi } \\
\text { aktivator(\%) }\end{array}$ & Kadar air(\%) \\
\hline 1 & 2.5 & 13.04 \\
2 & 5 & 8.69 \\
3 & 7.5 & 6.95 \\
\hline
\end{tabular}

Dari tabel diatas diketahui bahwa kadar air karbon aktif maksimal terdapat pada karbon aktif yang disintesis pada konsentrasi activator 2,5\% yaitu sebesar $13,04 \%$. Sedangkan kadar air minimal terdapat pada karbon aktif yang konsentrasi activator 7,5\% yaitu sebesar 6,95\%. Hal ini menunjukkan kualitas karbon aktif yang 
dihasilkan dalam penelitian ini cukup baik. kadar air yang terkandung sesuai persyaratan menurut SNI 06-3703-1995 yaitu maksimum 15\%.

\section{c. Uji Kadar Abu}

Kadar abu merupakan banyaknya kandungan oksida logam yang terdiri dari mineral-mineral dalam suatu bahan yang tidak dapat menguap pada proses pengabuan.

Tabel 2. Hubungan antara konsentrasi aktivator dengan kadar abu.

\begin{tabular}{ccc}
\hline No. & $\begin{array}{c}\text { Konsentrasi } \\
\text { aktivator(\%) }\end{array}$ & Kadar abu(\%) \\
\hline 1 & 2,5 & 9,8 \\
2 & 5 & 4,47 \\
3 & 7,5 & 2,38 \\
\hline
\end{tabular}

Dari tabel diatas terlihat bahwa kadar abu karbon aktif meningkat dengan semakin rendahnya konsentrasi aktivator. Kadar abu karbon aktif maksimal terdapat pada karbon aktif yang disintesis pada konsentrasi 2,5\% yaitu sebesar 9,8\%. Sedangkan kadar abu minimal terdapat pada karbon aktif yang disintesis pada suhu 7,5\% yaitu sebesar 2,38\%. Keseluruhan kadar abu yang diperoleh pada penelitian ini telah memenuhi SNI 06-3703-1995 yaitu dibawah $10 \%$.

Hasil penelitian ini menunjukkan adanya kecenderungan semakin tinggi konsentrasi aktivator maka kadar abu semakin menurun. Pada arang aktif, kadar abu diupayakan sekecil mungkin karena akan menurunkan kemampuan daya serapnya baik dalam bentuk gas maupun larutan. Kandungan abu dapat berupa kalsium, kalium, magnesium dan natrium. yang dapat menutup dan menghalangi pori-pori arang aktif.

Peningkatan kadar abu dapat terjadi akibat terbentuknya garam-garam mineral pada saat proses pengarangan yang bila dilanjutkan akan membentuk partikel-partikel halus dari garam mineral tersebut. Hal ini disebabkan karena adanya kandungan bahan mineral yang terdapat di dalam bahan awal biomassa pembuat karbon.

d. Uji daya serap Iodium

Daya adsorpsi karbon aktif terhadap iod memiliki korelasi dengan luas permukaan dari karbon aktif. Semakin besar angka iod maka semakin besar kemampuannya dalam mengadsorpsi adsorbat atau zat terlarut Untuk bilangan Iodin akan semakin bertambah, daya serap terhadap Iod semakin besar dengan tingginya konsentrasi aktivator, ini berarti bahwa kualitas arang aktif akan semakin baik dalam penyerapan. Luas area permukaan pori merupakan suatu parameter yang sangat penting dalam menentukan kualitas dari suatu karbon aktif sebagai adsorben. Hal ini disebabkan karena luas area permukaan pori merupakan salah satu faktor yang mempengaruhi daya adsorpsi dari suatu adsorben.

Kereaktifan dari karbon aktif dapat dilihat dari kemampuannya mengadsorpsi substrat. Daya adsorpsi tersebut dapat ditunjukkan dengan besarnya angka iod yaitu angka yang menunjukkan seberapa besar adsorben dapat mengadsorpsi iod. Semakin besar nilai angka iod maka semakin besar pula daya adsorpsi dari adsorben. Penambahan larutan iod berfungsi sebagai adsorbat yang akan diserap oleh karbon aktif sebagai adsorbennya. Terserapnya larutan iod ditunjukkan dengan adanya pengurangan konsentrasi larutan iod.

Pengukuran konsentrasi iod sisa dapat dilakukan dengan menitrasi larutan iod dengan natrium triosulfat $0,1 \mathrm{~N}$ dan indikator yang digunakan yaitu amilum. Peningkatan bilangan Iod terjadi sebagai akibat semakin banyaknya pengotor yang terlepas dari permukaan karbon aktif. Seiring dengan peningkatan konsentrasi aktivator, pengotor-pengotor yang mulanya terdapat pada bagian pori dan menutupi pori, ikut terlepas atau teruapkan sehinggga memperluas permukaan karbon aktif. Semakin besar luas permukaan karbon aktif maka semakin besar kemampuan adsorpsi karbon aktif.

Dari hasil penelitian bilangan iodin karbon aktif meningkat dengan semakin tingginya konsentrasi aktivator. Daya serap iodin karbon aktif maksimal terdapat pada karbon aktif yang disintesis oleh asam posfat pada konsentrasi 7,5\% yaitu sebesar $602,91 \mathrm{mg} / \mathrm{g}$. Sedangkan daya serap iodin minimal terdapat pada karbon aktif yang disintesis oleh asam posfat pada konsentrasi 2,5\% yaitu sebesar 571,18 mg/g. daya serap iodin yang diperoleh pada penelitian ini telah memenuhi SNI 06-3703-1995 yaitu minimal $750 \mathrm{mg} / \mathrm{g}$. 
Tabel 3. Hubungan antara konsentrasi aktivator dengan bilangan iodium.

\begin{tabular}{ccc}
\hline No. & $\begin{array}{c}\text { Konsentrasi } \\
\text { activator(\%) }\end{array}$ & Bilangan Iodium (mg/g) \\
\hline 1 & 2,5 & 571,185 \\
\hline 2 & 5 & 590,22 \\
3 & 7,5 & 602,91 \\
\hline
\end{tabular}

e. Uji Kristalinitas

Pengujian dengan difraktometer sinar- $x$ (XRD) bertujuan untuk mengetahui derajat kristalinitas (X), jarak antar lapisan (d), tinggi lapisan aromatik (Lc) dan lebar lapisan aromatik (La) serta jumlah lapisan aromatiknya (N). Pada penelitian ini karakteristik struktur kristalin dilakukan terhadap arang tempurung kemiri, dan arang aktif dengan konsentrasi 2,5\%, 5\% dan $7,5 \%$.

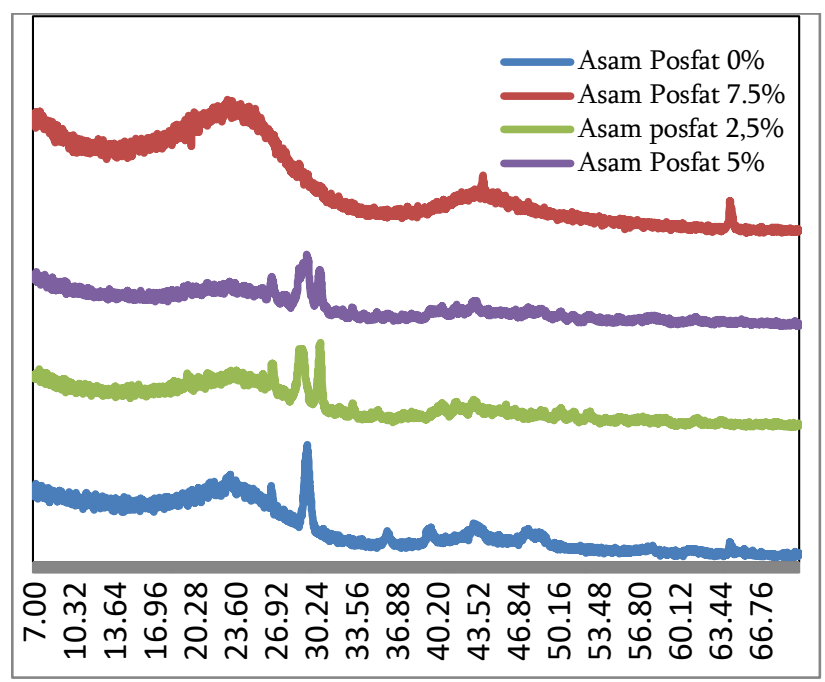

Gambar 1. Hasil uji XRD karbon aktif dengan konsentrasi aktivator $0 \%, 2,5 \%, 5 \%$ dan 7,5\%.

\section{KESIMPULAN DAN SARAN}

Karbon aktif dapat diperoleh dari kulit kemiri yang diaktifkan dengan menggunakan zat aktivator berupa $\mathrm{H} 3 \mathrm{PO} 4$ dengan konsentrasi 2,5\%, 5\% dan 7,5\% selama 24 jam dan disintering pada suhu $700^{\circ} \mathrm{C}$. Karbon aktif yang dihasilkan cukup baik dan memenuhi standar SNI dengan hasil pengujian kadar air yaitu antara 6,95\%-13,04\% dimana standar SNI maksimum $15 \%$, hasil pengujian kadar abu maksimal yaitu $9,81 \%$ dengan standar SNI minimum $10 \%$. daya serap iodin $602,91 \mathrm{mg} / \mathrm{g}$ dengan standar SNI minimum $750 \mathrm{mg} / \mathrm{g}$. Dari uji kualitas karbon aktif yang dilakukan, kualitas karbon aktif yang terbaik diperoleh pada konsentrasi asam posfat 7,5\% dengan kadar air
6,95\%, kadar abu 2,38\%, daya serap terhadap kadar iod sebesar 602,91 mg/g yang memenuhi standar SNI 06-3703-1995. Hasil yang di dapat dari penelitian ini yaitu semakin tinggi konsentrasi zat aktivator, dan waktu aktivasi maka semakin tinggi daya serap karbon aktif.

\section{DAFTAR PUSTAKA}

Anonim., (1995), Mutu dan Cara Uji Arang Aktif Teknis. Standar Nasional Indonesia (SNI) 06-3730-1995, Dewan Standarisasi Jakarta, Sekretariat Jenderal Kehutanan. Biro Perencanan, Jakarta

Laos,L.E, Masturi, dan Yulianti I, (2016), Pengaruh Suhu Aktivasi Terhadap Daya Serap Karbon Aktif Kulit Kemiri, Prosiding Seminar Nasional Fisika, Vol.5, hal: 135-140

Meilita, T.S. dan Tuti, S.S., (2003), Arang Aktif

(Pengenalan Dan Proses

Pembuatannya), Skripsi, Fakultas

Teknik, Universitas Sumatera Utara, Medan

Pari, G. dan Sailah, I., (2001), Pembuatan Arang Aktif Dari Sabut Kelapa Sawit Dengan Bahan Pengaktif NH4HCO3 Dan (NH4)2CO3 Dosis Rendah, Bogor

Sudrajat, R. dan Gustan Pari., (2011), Arang Aktif, Teknologi Pengolahan dan Masa Depannya, Badan Penelitian dan Pengembangan Kehutanan, Jakarta

Wulandari, dkk. (2012), Pengaruh Temperatur Pengeringan Pada Aktivasi Arang Tempurung Kelapa Dengan Asam Klorida dan Asam Fosfat Untuk Penyaringan Air Keruh. ITM- 05, halaman 289-293 